ARtigos "TraduZIDOS/

TRANSLATED ARTICLES 


\title{
A TERRA AMA E A BORDA ESTRANGEIRA UMA ARQUEOLOGIA DA TRADUÇÃO NA FRANÇA ${ }^{1}$
}

\author{
Antoine Berman \\ Centre Jacques Amyot \\ Tradução de Gilles Jean Abes* \\ Universidade Federal de Santa Catarina
}

\section{A França no espelho da tradução}

Goethe escreveu em 1828 a Carlyle:

... Essas relações do original com a tradução são [...] as que expressam mais claramente as relações de nação a nação, e as que devemos julgar preferencialmente [...] para o avanço da literatura mundial. ${ }^{2}$

Se dermos completo alcance a essa reflexão do poeta alemão, chegamos ao seguinte: a tradução é um espelho onde se reflete, de forma concentrada, a relação que uma cultura mantém com o estrangeiro. Eu

\footnotetext{
${ }^{1}$ Berman, Antoine. La terre nourrice et le bord étranger. In: Communications, 43 , 1986. Le croisement des cultures. pp. 205-224. Este texto é uma versão modificada de um seminário sobre a língua materna, a tradução e as línguas estrangeiras, que foi dado em maio de 1984 no Collège international de philosophie (Paris). [Nota do Editor no original]

* Professor adjunto do DLLE na Universidade Federal de Santa Catarina e professor permanente do programa de Pós-Graduação em Estudos da Tradução (UFSC). Possui doutorado no Programa de Pós-graduação em Estudos da Tradução. E-mail: gillesufsc@gmail.com

${ }^{2}$ In: Fritz Strich, Goethe und die Weltliteratur, Berne, Francke Verlag, 1946, p. 20. [Nota do Autor]. As notas subsequentes são de autoria do Antoine Berman.
} 
proponho explorar aqui a relação da cultura francesa com o Estrangeiro a partir do estatuto simbólico que ela atribui ao ato de traduzir.

Ouvimos frequentemente na França que nosso país não é um país de tradução; que nele pouco se traduz, e muito mal. Aqueles que arriscam tais afirmações o fazem com um tom resignado, como se se tratasse de um estado das coisas do qual não se pode alterar nada, porque essa "Falha de tradução" (para empregar uma expressão de Freud) é um traço estrutural do "espírito" francês. Na mesma ordem de ideias, afirma-se de bom grado que os franceses não se interessam pelo estrangeiro. Estas duas afirmações, com toda certeza, se complementam.

Ora, essa dupla imagem que temos de nós mesmos não corresponde à realidade. Mais especificamente: ela de fato tem base em defeitos reais, mas, a partir deles, se constitui como representação que os ultrapassa e não precisa mais deles, nem para serem confirmados nem para serem invalidados. Se traduzimos mais do que outrora na França, e frequentemente muito bem; se os franceses são cada vez mais atraídos pelo Estrangeiro, isso não modifica em nada a maneira com a qual percebemos nossa relação com a tradução e o Estrangeiro. Essa distância entre imagem e realidade, podemos perceber sua data de surgimento: foi na metade do século XVI, com du Bellay, que nasceu a ideia segundo a qual, para a cultura francesa, a tradução e a relação com o Estrangeiro que ela implica representam algo negativo. Se nós (re)lermos a obra de du Bellay, percebemos que nela ata-se uma relação com a língua e a cultura nacionais que constitui uma rejeição consciente do ato de traduzir e da abertura ao "Outro". Esta relação continua a reger profundamente a maneira pela qual percebemos nossa língua e cultura.

\section{Uma curiosa negação}

Sabemos que du Bellay negou que a tradução fosse para nossa cultura um modo de constituição e de ampliação fundamental. ${ }^{3} \mathrm{E}$

${ }^{3}$ Defesa e ilustração da língua francesa, cap. V. 
o fez em nome de uma certa ideia desta cultura, que amplamente contribuiu a fundar. Ora, essa negação ignora totalmente a realidade das coisas em sua época. Gustave Lanson, em sua História da literatura francesa, observa que:

depois do Pantagruel de Rabelais, depois do Instituto de Calvino, o Plutarco de Amyot é o mais considerável esforço fornecido pela língua francesa na sua tentativa de igualar as línguas antigas: ele torna Montaigne possível. ${ }^{4}$

Façamos as contas: nossa língua literária se constituiu na base de uma obra autóctone, o Pantagruel, que comporta aliás numerosos elementos multilíngues e tradutivos; na de uma autotradução, o Instituto de Calvino; na de uma grande tradução, o Plutarco de Amyot. A tradução ou, de forma mais genérica, o elemento tradutivo, portanto é preponderante, e nada tem de espantoso nisso, pois é um fato que caracteriza todas as culturas européias desde Roma: em todo lugar, em graus diferentes, a tradução teve um papel fundamental. A obra de du Bellay em si é impensável sem um longo trabalho de tradução, sem um longo e íntimo comércio com o latim, o grego e o italiano. O que é espantoso, é que este poeta - e toda sua época após ele - tenha se aplicado a negar essa realidade!

\section{Por que du Bellay?}

Proponho aqui uma "arqueologia" que levará em conta a totalidade da obra de du Bellay, mesmo que nela apareça uma figura negativa da tradução profundamente inscrita em nossa cultura.

Essa obra é ao mesmo tempo diminuta e variada: obras poéticas em francês, poemas em latim, textos "doutrinários", e algumas traduções. Certa tensão reina entre estas obras, já que du Bellay, ao

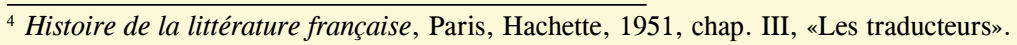


mesmo tempo em que preconiza a escrita em francês, escreve também em latim, e, ao mesmo tempo em que proscreve a tradução, traduz Virgílio, por exemplo. Há nesse ponto uma "contradição" remetendo tanto à problemática do autor quanto à de todo o século XVI: impossível, de fato, distinguir as duas coisas, pois tudo que du Bellay sente, ganha sentido somente porque ele é poeta-do-francês, e é nisso que seu destino pessoal simboliza o de todo uma época. Além disso, du Bellay não é para nós um poeta do século XVI dentre outros: é nele em quem se resolveu e manifestou certa relação com a língua nata - e por muito tempo. Desse poder de interpelação, em pleno século XX, testemunham as Belas Infiéis de George Mounin (para a tradução) e o Tombeau de du Bellay [Túmulo de du Bellay] de Michel Deguy (para a poesia).

\section{Les Regrets [As Lamentações]}

À diferença de Mounin, cujo livro não é senão uma longa explicação crítica da Defesa e Ilustração..., abordarei esta obra pela poesia, e mais especificamente por Les Regrets, pois é nessa coletânea que aparece com maior evidência essa nova relação com a língua nata que motiva a rejeição da tradução, mesmo se, cronologicamente, essa rejeição é anterior ${ }^{5}$.

Todos nós aprendemos no colégio que du Bellay, de 1553 a 1557, fez uma estadia em Roma, e que esta estada, veementemente desejada, tornou-se rapidamente para ele uma prova insuportável. No seu retorno à França, o poeta publica Les Regrets, assim como les Antiquités de Rome, les Jeux rustiques e os Poemata (em latim). Les Regrets expressam simultaneamente a "nostalgia" do país natal e a execração do país estrangeiro. A posteridade e os manuais lembraram sobretudo dos poemas nostálgicos, o que é somente em parte justo.

Primeiro, tudo ocorre como se du Bellay, em Roma, vivesse uma crise poética, em decorrência do afastamento com a França:

${ }^{5}$ A Defesa... é de 1549, o Les Regrets de 1558. 
et les Muses de moi, comme étranges, s'enfuient ${ }^{6}$ (soneto 6)

[e as Musas de mim, como estranhas, fogem]

Certamente, em Roma, du Bellay escreve muito. Mas não encontra força poética feliz senão para evocar a terra e a língua pátria; assim que fala da terra estrangeira, esta força o abandona e o condena a ser - aos seus próprios olhos - apenas um amargo rimador.

\section{A borda estrangeira}

Estranho, para um homem do Renascimento, essa relação de du Bellay com Roma e a Itália. Nem o fasto da cidade, nem suas antiguidades, nem o pátio papal encontram encantos aos seus olhos. Ele conta o fato para Ronsard:

Il n'a humé l'ardeur que l'Italie enflamme (soneto 8)

[Ele não sorveu o ardor que a Itália inflama]

Em toda parte, nessa coletânea, retorna a queixa de se encontrar sobre o que ele chama:

le bord étranger (sonetos 10, 27,37, 93),

le bord inconnu d'un étrange rivage. (soneto 16)

[a borda estrangeira/ a borda desconhecida de uma estranha margem]

${ }^{6}$ Les Regrets, Paris, Livre de poche, Hachette, 1967. Todas as citações têm por referência essa edição.

Cad. Trad., Florianópolis, v. 37， no 3， p. 280-304, set-dez 2017 
A Ronsard, que lhe escreve em 1555:

Cependant que tu vois le superbe rivage de la rivière tusque et le Mont Palatin et que l'air des Latins te fait parler latin changeant à létranger ton naturel langage...

[Enquanto vê a soberba margem/ do rio tusco e o Monte Palatino/ e que o ar dos Latinos fez-te falar latim/ no estrangeiro mudando tua natural linguagem...]

ele responde no soneto 10:

Ce n'est pas le fleuve tusque au superbe rivage

Qui ores, mon Ronsard, me fait parler latin, changeant à l’étranger mon naturel langage C'est l'ennui...

[Não é o rio tusco com soberba margem/ .../ Que agora, caro Ronsard, faz-me falar latim,/ no estrangeiro mudando minha natural linguagem/ É o tédio...]

Pois é um fato: du Bellay em Roma escreve em francês e em latim. Mas escrever em latim é experienciado de alguma forma como uma traição, como o fato de sucumbir ao chamado da língua estrangeira. O estrangeiro é, para du Bellay, objeto de uma repulsa fascinada, e este sentimento o petrifica, lhe faz temer jamais poder retornar à França. Du Bellay está aterrorizado por Roma. O que o aterroriza, é a manifestação crua e polimorfa do desejo. $\mathrm{O}$ «ardor italiano», é isso: 
Si je vais plus avant, quelque part où $\mathrm{j}$ 'arrive je trouve de Vénus la grande bande lascive dressant de tous côtés mille appâts amoureux (soneto 80)

[Se eu vou adiante, aonde chego/ encontro Venus a grande banda lasciva/ elevando de todo lado mil amorosos encantos]

Repulsa e fascínio se unem aqui:

Qui choisira pour moi la racine d'Ulysse?

Et qui me gardera de tomber au danger

qu'une Circé en pourceau ne me puisse changer...

Qui chassera de moi ces harpies friandes? (soneto 88)

[Quem para mim escolherá a raiz de Ulisses?/ E quem me impedirá de no perigo quedar/ uma Circe em porco me transformar/ .../ Quem de mim afastará essas harpias ávidas?]

Daí a conjuração pelo mito e a Antiguidade: Ulisses aqui, algures Eneias. Tudo ocorre como se a "borda estrangeira" fosse o lugar do desejo, do desejo do qual du Bellay se esquiva porque nele entoa o apelo de um outro desejo, o da "terra ama", e é o canto deste desejo que garantiu sua glória poética em nosso país.

\section{A terra ama}

Muitos sonetos $(19,30,31,36$, etc.) cantam a terra natal e o lar: toujours de la maison le doux désir les point (soneto 30).

[sempre do lar o doce desejo os acomete] 
E o famoso soneto 31, Feliz quem como Ulisses, que opõe o "pequeno Liré" ao "monte Palatino": Les Regrets, para nós, é isso antes de mais nada.

Dir-se-á: o poeta está "nostálgico". E observaremos, em sua existência, o que pode explicar seu medo do desejo e essa "regressão" ao "colo materno". Mas, na verdade, essa desolação que acomete o poeta em Roma, é preciso entendê-la a partir da posição simbólica que ele ocupa enquanto poeta francês. Du Bellay é poeta francês - e sobretudo - poeta régio. É enquanto tal que vive a borda estrangeira, o desejo que se desenfreia, literalmente, na língua estrangeira, oposto ao "doce" desejo do lar. A ligação com o "materno" deve ser entendido a partir do fato que du Bellay é poeta da língua materna régia. $O$ francês é a língua mãe, e, nos harmoniosos poemas consagrados ao Anjou, vemos entrelaçar-se língua e paisagem em uma unidade indissociável. Que a terra natal seja para ele uma "mãe", o soneto 9 o atesta.

France, mère des arts, des armes et des lois... tu m'as nourri longtemps du lait de ta mamelle.

Ores, comme un agneau qui sa nourrice appelle, je remplis de ton nom les antres et les bois.

Entre les loups cruels j'erre parmi la plaine, je sens venir l'hiver, de qui la froide haleine d'une tremblante horreur fait hérisser ma peau.

França, das artes mãe, das armas e das leis. Muito tempo nutriu-me o leite de tua mama. Agora, qual cordeiro, aflito que à mãe chama, $\mathrm{Eu}$ encho com teu nome os antros e vergéis.

Entre os lobos cruéis eu erro pelo prado, Sinto chegar o inverno, e seu bafo gelado Eriça minha pele e faz tremer de horror. ${ }^{7}$

7 Tradução de Mário Laranjeira. Há pequenas diferenças nas maiúsculas iniciais e na pontuação entre a tradução e o texto citado pelo Berman. [Nota do tradutor] 
Mas, então, de onde vem que, no soneto 27, Du Bellay opõe borda estrangeira à "margem paterna" - e não materna? Porque o país e a língua natais são "franceses" apenas no que relevam de outra instância: o rei. Shakespeare fala dos soberanos dizendo: "França”, "Inglaterra", etc. O Anjou natal não é somente uma paisagem campestre onde o poeta teria passado sua infância: é a estadia dos reis, que lá semearam seus castelos. É a Terra-do-rei. Da mesma forma, a língua ama não é apenas o idioma natal, é a Língua-do-rei. A França é mãe das artes, das armas e das leis somente porque foi fecundada pelo rei, e por este rei que tem por nome simbólico Francisco Primeiro:

Dessous ce grand François, dont le bel astre luit au plus beau lieu du ciel, la France fut enceinte des lettres et des arts...

[Sob esse grande Francisco, cujo belo astro reluz / no mais belo lugar do céu, a França foi emprenhada / das letras e das artes...]

Nesse contexto, o fato de Du Bellay ter introduzido o termo de pátria em francês certamente não é indiferente.

Portanto, a margem é paterna pois é o lugar-do-rei. É por ele que "França" foi fecundada. E tal é a relação que se estabelece no fim das Lamentações, com os dez sonetos dedicados ao rei e à irmã Marguerite, filha de Francisco I e protetora do poeta. Há uma correspondência precisa, termo por termo, entre o soneto 31, que celebra o país angevino, e o soneto 81 , no qual Du Bellay opõe a pompa romana à simplicidade de Marguerite. Não se pode, de forma alguma, apreender a relação do poeta com sua língua e a natureza dilacerada de seu desejo se não percebermos o lugar que ocupa, no seu universo simbólico, o que ele chama de "espírito real”, que já compara a um "sol”. Os sonetos 176 e 191 (o último da obra) descrevem a figura do rei em termos platônicos: 
Esprit royal, qui prends de lumière éternelle ta seule nourriture et ton accroissement

...

au seul objet divin de ton image pure

se meut tout mon penser...

[Espírito real, que toma da luz eterna / teu único alimento e teu crescimento / ao único objeto divino de tua imagem pura / se move todo o meu pensar]

\section{O Francês e o Italiano}

Tal é o dispositivo de imagens no seio do qual a "língua natural e materna francesa" (Rabelais) se torna a língua régia, língua regida no sentido literal do termo. E é o que vai fundar seu lugar na hierarquia das línguas. $\mathrm{O}$ francês é superior às outras vulgares no sentido em que é língua régia que vai se tornar, nos séculos seguintes, língua dos reis. E da mesma forma que o rei detém sua essência de Deus, o francês detém sua excelência do latim, que é para ele a língua pai. Francisco I, pelo edito de Villers-Cotterêts, instituiu o francês como língua da lei; com múltiplos decretos, instituiu-o língua das ciências e das artes. Direi aqui algumas palavras sobre o italiano como língua culta rival, e da relação antagônica que Du Bellay entretém com ele. Primeiro, sua obra l'Olive deve muito a Petrarca. Além disso, para redigir a Defesa... ele praticamente copiou uma obra de Speroni publicada em Veneza em 1542, que defendia a língua italiana: tanto é que a Defesa e Ilustração do francês não é senão uma retomada da defesa e ilustração do italiano! Em Les Regrets, encontramos simultaneamente italianismos e pesados sarcasmos contra a língua italiana. De fato, tudo ocorre como se essa língua, fundamento do "renascimento" da língua francesa, fosse negada como tal, e isto, como veremos, aparenta-a à tradução. Esse paralelismo não é gratuito, pois o italiano, na época, é verdadeiramente a língua-da-tradução. É um italiano, Giordano Bruno, quem 
ousou dizer: "da tradução advém toda ciência". Mais profundamente, o impulso à tradução, que se espalha por toda a Europa, é coisa italiana, e na França a rejeição da Itália será indissociável daquela da tradução. Mas tem mais: o estatuto simbólico da koiné italiana é totalmente oposta àquele da koiné francesa.

Em vários sonetos, du Bellay descreve o sentimento de "frio" que lhe invade ao sentir-se distante da França, ao sentir-se, nas "encostas ensolaradas" de Roma, longe do sol régio. Du Bellay, paradoxalmente, sente frio justamente no lar do "ardor" italiano, este ardor que é aquele da língua da qual Milton dirá ainda que é a lingua di cui se vanta amore.

Em comparação a Ronsard, que vive no esplendor da presença real, du Bellay é como que expulso desse corpo essencial fora do qual ele não é senão frio e desolação. O horror do italiano é aquele da língua estrangeira vivenciada como a língua do outro desejo do qual tenta escapar, pois isso o distanciaria irremediavelmente daquele corpo. Ora, dele, du Bellay é literalmente um dos seus membros. Pois o verdadeiro ilustrador da língua francesa, ou antes a Figura a partir da qual é inaugurada toda "defesa e ilustração da língua francesa", é o Rei. Nesse sentido, du Bellay estabeleceu com sua língua natal um pacto exigente. O Estrangeiro é o lugar da perda do corpo simbólico, assim como para Ulisses e Eneias. Perante o desenfreamento do desejo encarnado pela lingua di cui se vanta amore, "harpia" e "sereia", a língua francesa vai se constituir para du Bellay e seus sucessores como a língua do desejo regido e reprimido. ${ }^{8}$ Neste poeta aparece então toda uma configuração que será decisiva para a língua e a poesia francesas. A língua régia tende a formar um corpo fechado, quarto dos amores legítimos e legiferantes do rei e de sua língua - do qual o rei, poetas, gramáticos, tradutores, etc., constituem os membros e órgãos fecundos. Este estatuto simbólico do francês, todos os textos da época, aqueles do rei como aqueles de seus súditos, atestam-no.

${ }^{8}$ Que o italiano se torne na Europa a língua-do-desejo, eis aí um estatuto que remonta a Dante, que escreveu: "Eu farei, ao falar, enamorarem-se as pessoas..." (Vita Nuova). 


\section{A língua e o corpo heróico do Príncipe}

Étienne le Blanc, tradutor de Cícero (1530), diz de Francisco I que ele

deu graça, ornamento e venustade àquela [a língua] cujo nome carrega

e a "enriqueceu"para fazê-la mais fecunda que suas rivais. $\mathrm{O}$ rei

faz poetas e oradores como Duques e Condes,

ele é

Pai das Letras. ${ }^{9}$

Dûchatel, em sua oração fúnebre de Francisco I, diz:

Mas quem poderia não louvar aquele que pôs novamente adornos da Grécia em vida e vigor a poesia, a história, a filosofia em seu reinado [...]. O falecido Rei não somente honrou as letras majestosamente em seu reinado como fora dele, mas ainda as edificou e plantou em seu povo pela sua largueza e liberalidade ${ }^{10} \ldots$

${ }_{9}^{9}$ Revue des sciences humaines, Lille III, 1980-1984, 180, «Récrire, traduire, récrire», Luce Guillerm, «La topique de la traduction au XVIe siècle en France», p. 26-27.

${ }^{10}$ Ibid. 
Mas os próprios Decretos reais não dizem outra coisa e estão na origem de todos esses louvores. Assim o de 28 de dezembro de 1537, instituindo o depósito legal:

Como desde nosso advento à coroa, nós desejamos acima de tudo a restauração das boas letras, que durante muito tempo ficaram ausentes, ou então seu conhecimento tão impedido e encoberto pelas trevas da ignorância que elas não poderiam ser descobertas... mas graças a nosso Senhor, nós tanto fizemos e tão bem e trabalhamos com tanto zelo que a força primeira, luz e claridade das ditas boas letras foram por inteiro restituídas e dominadas em nosso reino o qual pode hoje afirmar-se acima de todos os outros... o mais enobrecido e florescente ${ }^{11} \ldots$

Como o diz Luce Guillerm em seu "Topique de la traduction au XVIe siècle em France", "é somente fundidos no corpo heroico do Príncipe que escritores e tradutores participam à grande obra criadora e conquistadora". O Príncipe é a "origem de todo valor". Daí decorre toda uma série de consequências: a perfeição real da língua leva a se fechar sobre si, a recusar qualquer contaminação. Para atingir essa pureza não misturada, o francês deve atingir um estatuto de modelo por todo um processo de imitação e assimilação das línguas antigas e de seus textos: tal será a obra do classicismo.

\section{Acuerdo-olvido}

A medida que nossa língua "digere" os helenismos, latinismos, italianismos, hispanismos... se instaura entre ela e as outras línguas

${ }^{11}$ Ibid. 
um desvio crescente, que tem origem em seu desejo de tornar-se língua modelo. Seu ideal de pureza não é de forma alguma a "língua nacional originária” de Herder, mas aquela da essência real. Este desvio pelo qual o francês se afirma como modelo não pode se constituir apenas pela imitação. De forma bastante paradoxal, imitar, é igualar. Imitar um modelo é tornar-se modelo. A grande rememoração da Antiguidade introduz a um esquecimento tanto mais profundo que se apresenta sob a figura da recordação, e é o lema do tradutor Herberay des Essarts, que assinava suas traduções por

\section{Acuerdo-olvido ${ }^{12}$}

Recordar/olvidar: tal é a imitação. Assim cresce o corpo da língua régia. Assim, declara du Bellay, agiram os Romanos. Com esta imitação assimilante, o francês se coloca a uma distância sideral das outras "vulgares", em um plano onde nenhum outro, em breve, poderá mais influenciá-lo.

A experiência romana de du Bellay assinala o nascimento desse estatuto simbólico de nossa língua, pelo qual o Estrangeiro é o negativo, o lugar da perda. Du Bellay é o primeiro a ter sentido o aferro à língua como língua régia. A partir daí nele se decide o estatuto e o destino da tradução, e, de maneira geral, para o século XVI francês. Este estatuto se decide no espaço da imitação, pois, como diz Peletier, traduzir, é primeiro imitar:

A mais verdadeira espécie de Imitação é de traduzir: pois traduzir não é outra coisa senão desejar fazer o que outro faz: como faz o tradutor que se sujeita não somente à Invenção alheia, como também à sua Disposição, e ainda à Elocução ${ }^{13}$.

${ }^{12}$ Revue des sciences humaines (RSH), p. 3.

${ }^{13}$ Ibid., Hélène Nais, “Traduction et imitation”, p. 35. 
Mas logo a tradução não aparece mais como a suprema forma da imitação, no que ela tem de por demais "servil”, por demais ligada ao original e à sua "elocução"; no que está detida em uma oposição essencial em todos os domínios no século XVI: a da liberdade e da servidão, a do "autor" e do "súdito". Tudo isso remete, aliás, ao "espírito real”, pois o rei é o Grande Autor, e ele o é porque "imita" o Autor divino. Podemos pressentir o que vai ocorrer com tal simbologia: se ser autor, é ser "como" o rei, ser tradutor, é ser como o que?

\section{Du Bellay tradutor}

Pouco antes de sua partida para Roma, du Bellay publica uma tradução do quarto livro da Eneida, o livro dedicado aos amores de Eneias e Dido; tradução acompanhada de um poema de Ovídio sobre o mesmo tema e de uma peça original inspirada em Ausônio, o “Épigramme sur la statue de Didon”. É preciso saber que os amores da rainha e de Eneias exercem na época uma imensa fascinação, e suscitam muitas traduções e imitações, tudo isso culminando com a tradução da Eneida por des Masures e com a tragédia de Jodelle, Didon se sacrifiant. Du Bellay justifica sua tradução dizendo

que não se encontra obra em qualquer língua que seja na qual as paixões amorosas são tão profundamente pintadas ${ }^{14}$.

Eis aí, se levarmos em conta o fato de que este livro da Eneida canta o sacrifício do amor à "razão política", algo que está ligado ao estatuto do desejo regido, como mencionado mais acima. No caso de du Bellay, essa tradução/imitação é bastante significativa. Primeiro, porque, ao traduzir Virgílio, o poeta violenta o princípio estabelecido em sua Defesa... "de não traduzir os poetas",

${ }^{14}$ In: Hélène Nais, op. cit., p. 35. 
princípio que aceitava apenas uma exceção: as traduções poéticas encomendadas pelo Príncipe (e é verdade que nesse contexto, não é um detalhe). Mas nenhum príncipe, ao meu conhecimento, pediu-lhe para traduzir Virgílio. Em seguida, porque o texto traduzido prefigura sua experiência romana: Du Bellay se identifica com Eneias. Este é o fundador de Roma, assim como o poeta está ligado à "fundação" do francês. Como Eneias, du Bellay sofre o fascínio da "Rainha estrangeira". Tudo acontece como se, antes de pôr à prova, pela ausência, seu pertencimento ao corpo régio, o poeta vivesse esta prova de dois modos sucessivos, cujo segundo elimina o primeiro: a tradução e a imitação. Em Cartago, Eneias se põe à prova do Estrangeiro para melhor reconhecer seu destino e pertencimento; Du Bellay vai a Roma para fazer a mesma experiência, não sem tê-la mimada poeticamente.

Ora, esta mímica, observemos que é primeiramente a tradução como transgressão e inversão da relação de du Bellay com o latim: transgressão já que houvera proibição, inversão, já que du Bellay escreve geralmente em latim, ao invés de traduzi-lo. A "paixão amorosa" lhe é somente acessível pela transgressão/inversão. Mas, ao mesmo tempo, a tradução não é senão o primeiro momento da apropriação do "tema"; o segundo, o verdadeiro, é a imitação e aqui se anuncia porque a tradução vai ser condenada em proveito da imitação. Pois a tradução faz ressoar sem distância a voz da paixão estrangeira na língua traduzinte. Na tradução, o mestre é o original, o desejo não regido. A imitação, por outro lado, nada devendo à letra do original, não é mais a mímica subjugada ao desejo estrangeiro, mas sua jugulação. O que desejo mostrar aqui é como e por que a tradução foi desapossada pela imitação, e como ela tornou-se, para subsistir, um modo de imitação segundo e suspeito, um pouco como, no século XIX, tornou-se um modo segundo da crítica e da hermenêutica. Isso permite compreender o que funda a retórica antitradutiva da Defesa..., que Mounin estima "racionalmente" refutável. Refutável, ela o é, mas isso não diz respeito ao nível simbólico onde está em jogo todo o ser de uma língua, uma poesia e uma cultura. Na Defesa... du Bellay estaria sendo 
superficial? Pouco importa, se fala a partir de uma Lei pela qual a tradução não pode ter um lugar, sendo a afirmação da não-distância e da acasalação. Traduzir é expor a língua materna ao "ardor" (ao "perfume", diria Dante) da outra língua.

Portanto, a tradução de Virgílio serve a du Bellay para provar concretamente que a tradução deve ser rejeitada. Tem o mesmo sentido que a estadia em Roma: uma prova negativa do Estrangeiro.

\title{
A rejeição da tradução
}

A partir daí, nós podemos reler a Defesa... e tomar a medida desse grande movimento de rejeição da tradução anunciado na França a partir dos anos $1450^{15}$. Rejeição tão profundo que um Montaigne, apesar de tradutor e viajante, pode simultaneamente fazer a apologia do contato com o Outro, celebrar Amyot e condenar a tradução:

\begin{abstract}
É boa coisa traduzir os autores nos quais há muita pouca matéria para se representar; mas aqueles que muito contribuíram à graça e elegância da linguagem, são perigosos de se empreender ${ }^{16} \ldots$
\end{abstract}

Contradição tão impressionante quanta aquela que leva este grande "citador" a pretender escrever unicamente a partir dele mesmo, como se este "ele mesmo" nada tivesse a ver com o fato que ele "cita". As duas coisas estão ligadas, pois citar é introduzir um outro no texto, e a tradução não faz outra coisa.

\footnotetext{
${ }^{15}$ Ver, sobre este assunto, o artigo de Luce Guillerm.

${ }^{16}$ In: Les Belles infidèles, de Georges Mounin, p. 17. A apologia da viagem se encontra em Descartes, no Discurso do método. Seria proveitoso estudar no filósofo a relação com a tradução, o latim e o francês, assim como com os temas da liberdade e da servidão, da "paixão" e do "real" (sem falar das "rainhas estrangeiras", Elizabete e Cristina); observar como essas dimensões já presentes no século XVI em du Bellay e Montaigne se rearticulam com ele. Não é por acaso se Descartes viveu quase toda sua vida fora da França.
} 
Certamente, essa rejeição da tradução na França não poderia ser tão simples. Por vários motivos. Primeiro, as traduções tinham constituído o próprio solo do desenvolvimento das letras e das ciências, como em toda parte na Europa. Francisco Primeiro e seus sucessores as incentivaram. Finalmente, como mostra o texto de Peletier, em uma cultura que colocava a imitação como o gesto cultural supremo, a tradução aparecia, à primeira vista, como o ato recriador por excelência ${ }^{17}$. Mas a partir de 1450 aproximadamente, ou seja, na época dos Regrets, o discurso sobre a tradução muda, e isto está ligado a uma reinterpretação da essência da imitação, ao surgimento da "livre" imitação, perante a qual a tradução não é senão imitação "servil". Este conceito altera por sua vez a tradução e transforma-a no nosso país - por muito tempo - em imitação "livre".

A base desta mudança é a auto-afirmação de nossa língua. Amyot e todos os tradutores du século XVI enriqueceram o francês. Mas este movimento, longe de prosseguir, como por exemplo na tradição alemã, interrompe-se assim que se tratou de fazer do francês um todo fechado e não misturado. A partir desse momento, traduzir aparece como uma prática de contaminação contrária ao "gênio" de nossa língua. Mais especificamente, ela aparece como uma prática de contaminação servil; porque, ligada a letra dos originais, introduz necessariamente formulações estrangeiras ou obriga - dizem tanto Dolet quanto du Bellay - a "empregar palavras pouco frequentes". Rabelais já condenava em Pantagruel a propósito do Estudante limusino aqueles que "desdenhavam o uso comum do falar". Em outras palavras, é toda a essência da tradução que,

${ }^{17}$ Todo mundo, no século XVI, imita todo mundo. É o que demonstra a sequência seguinte. Du Bellay traduz um verso de Virgílio assim:

Et des Palais le front audacieux... [E dos Palácios a fronte audaciosa...]

Ele "imita" este verso nos Regrets:

Que des palais romains le front audacieux... [Que dos palácios romanos a fronte audaciosa...]

Ronsard, por sua vez, "imita” du Bellay:

De leurs superbes murs les fronts audacieux... [De suas soberbas muralhas as frontes audaciosas...]

(Hélène Nais, op. cit.)

Cad. Trad., Florianópolis, v. 37， no 3， p. 280-304, set-dez 2017 
a partir dessa época, torna-se duravelmente estrangeira à cultura francesa. Traduzir ou imitar, tal é o dilema colocado pela Defesa...

Sébillet, o adversário de du Bellay, concedia à tradução os méritos que irão competir à imitação:

... e deve-lhe a mesma glória que leva aquele que pelo seu labor e longa pena extrai das entranhas da terra o tesouro escondido para fazê-lo uso de todos os homens ${ }^{18}$.

Mas, rapidamente, o corte é feita entre a servidão da tradução e a liberdade da escrita. Entre o caráter "penoso" da tradução e o caráter "agradável" da escrita. A tradução constitui o lugar do esforço, do contato extenuante com a matéria (disposição e elocução) do texto estrangeiro. Assim Aneau declara:

É mais difícil e penoso seguir o outro pelo caminho desconhecido e estreito parando seus pés sobre seus rastros do que por livre e franca marca ir embora divertindo-se a bel prazer por um pleno e largo caminho descoberto ${ }^{19}$.

Chapelain dirá no fim do século:

Traduzir é coisa vil, e a tradução para aqueles que a professam pressupõe baixeza de coragem e depreciação do espírito ${ }^{20}$.

\footnotetext{
${ }^{18}$ Luce Guillerm, p. 10-17.

${ }^{19}$ Ibid. E Peletier: "Um tradutor jamais tem o nome de autor." O século XVI instaura uma cesura entre os autores e os "tradutores, comentadores, restaurados de livros corrompidos e outros sujeitos que seguem os rastros do outro" (Denis Sauvage). Mas, por outro lado, a tradução, ligada aos originais, permite ao século XVI deduzir a própria noção de original $e$ de autor. Os tradutores, diz Guillerm (op. cit.) são até mesmo os primeiros a estabelecer a distinção entre o autor e o não-autor, o original e o não-original. Paradoxo da experiência da tradução como experiência daquilo que é original, experiência se voltando contra ela!

${ }^{20}$ In: Romans picaresques espagnols, Paris, Pléiade, 1968, p. CLXXV.
} 
Atrás de tudo isso, há a condenação da tradução como introdutora de estranheza. Movimento que irá tão longe ao ponto de, no século XVII, as citações de Montaigne serem condenadas (por exemplo, por Malebranche), essencialmente porque contaminam com a palavra estrangeira a própria palavra. $\mathrm{O}$ autor é aquele que não deve se deixar dominar pela palavra e a língua do outro. Pode muito bem pedir-lhe emprestado formas e temas, retomar a "invenção", mas não deve "copiar". Imitar não é copiar. Assim sendo, a grande acusação dirigida contra a tradução é que esta é uma cópia. A tradição clássica e pós-clássica o repetirá até o fastio, de Voltaire:

Que não se creia conhecer os poetas pelas traduções, seria como querer perceber a cor de um quadro em uma estampa

até Chateaubriand:

A tradução não é a pessoa, é apenas um retrato ${ }^{21}$.

No horizonte da língua régia e da figura do autor que ela consagra, a tradução não pode aparecer senão como culpável sujeição à palavra do outro, mesmo que afirmasse, como Dolet, que

ao traduzir, não se deve sujeitar-se ao ponto de fazê-lo palavra por palavra... É superstição demasiadamente grande ${ }^{22} \ldots$

Mas essa condenação da cópia, é preciso saber interpretá-la: ao copiar, a tradução não fornece tanto uma imagem empalidecida do original, antes pura e simplesmente imagem, um duplo, e o que re-

${ }^{21}$ In: Mounin, op. cit., p. 26.

${ }^{22}$ In: Guillerm, op. cit., p. 17. 
jeita la teoria da imitação, é a relação original/cópia constitutiva da tradução; é que o momento do recordar (acuerdo) seja sempre aqui mais forte do que aquele do olvidar (olvido). Até que ponto essa recusa da alteridade é todo-poderosa, é o que revelam as reescrituras ao gosto daquele tempo, obras escritas em francês "antigo", como o Heptaméron de Marguerite de Navarre, se tornaram muito chocantes para os leitores clássicos ${ }^{23}$.

A língua régia recusa tanto a estranheza das línguas estrangeiras quanto aquela do seu passado balbuciante e grosseiro. Ela reescreve tanto as obras estrangeiras quanto suas próprias obras, por não atenderem mais às suas normas. Eis o que é preciso ler em filigrana em du Bellay, na decisão soberana de afastar a tradução como modo primordial de defesa e ilustração da língua francesa. A tradução incorre a mesma condenação que o Estudante limusino que latiniza seu francês.

\section{A intraduzibilidade}

Abordemos por fim a outra vertente da condenação de du Bellay: a intraduzibilidade da poesia. Essa afirmação é uma afirmação de valor: a poesia é intraduzível porque exalta a própria essência da língua. Mas isso significa: esta língua que recusa a tradução como modo de sua exaltação recusa também de ser traduzível. Afirmar a intraduzibilidade da poesia é afirmar que a singularidade régia da poesia não pode, não deve ser submetida à prova da tradução. Ora, é intraduzível apenas a poesia que se pôs como tal, e sabemos o quanto Racine, por exemplo, passa laboriosamente em outra língua, o quanto sua poesia quintessenciada (a própria imagem da língua do desejo regido) deixa-se pouco traduzir. A recusa da tradução é, portanto, em sentido duplo: traduzir de... ser traduzido para..., e a um primeiro sistema:

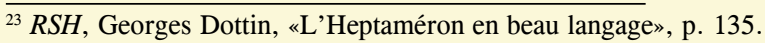


traduzir - ser traduzido

se substitui outro:

imitar - ser imitado

Pois uma cultura traduzinte é sempre uma cultura traduzida, e uma cultura imitante sempre uma cultura imitada. É lógico que o florescimento da cultura francesa tenha sobretudo passado por imitações. Com efeito, os séculos XVI e XVII franceses lançaram as bases de uma cultura generalizada da imitação que veio se substituir a uma cultura generalizada da tradução. E foi contra esta cultura que se ergueu a cultura da tradução da Alemanha romântica ${ }^{24}$. A cultura da imitação é tendencialmente uma negação da alteridade, a cultura da tradução tendencialmente uma abertura à alteridade.

É verdade que o século XVI era por demais dominado pelo impulso à tradução para que as coisas fossem tão categóricas quanto o século XVIII. Mas no momento em que a tradução aparece como imitação secundária, como uma cópia, seu destino está traçado, e a grandes traduções de Amyot e dos poetas do século XVI não mudarão nada à situação. Uma impossível dupla situação se criou: o tradutor é "livre" demais, é um "traidor"; é "fiel” demais, é um “escravo”. Não há espaço, na língua régia, para o ato de traduzir, para a relação com o Estrangeiro, exceto sob as espécies de uma fascinação dobrada de desprezo ${ }^{25}$.

${ }^{24}$ Ver Antoine Berman, L'Épreuve de l'Étranger, Paris, Gallimard, 1984.

${ }^{25} \mathrm{O}$ Estrangeiro, como lugar de desejo não ligado, fundamenta uma relação de atração e de repulsa. Visível em du Bellay, esta relação é localizável em seguida em três domínios: o Oriente, lugar de desejo desenfreado e concatenador, a Itália, lugar de desejo melodioso e cativante do qual zombará o Abbé Grégoire perante a Convenção, o universo do Selvagem (da América até Taiti). Em todos os casos, o Estrangeiro é o lugar do desejo rejeitado e percebido como uma mistura de liberdade e servidão. A tradução/imitação de Galand (as Mil e uma noites) testemunha da intensidade dessa relação. Com efeito, em nossa cultura, o Estrangeiro é aceito somente como fonte de imitações. 


\title{
A "nova" Eneida
}

Desse estatuto da língua e da tradução que aparece em du Bellay, ainda estamos tentando libertar-nos. Nem o romantismo nem a primeira metade do século XX com suas "revoluções poéticas" conseguiram verdadeiramente abalá-lo. Certamente, ele não corresponde mais à realidade, mas tem a solidez de uma representação que nos domina. E, a esse respeito, a tradução da Eneida por Pierre Klossowski representa um evento importante, porque ela rompe - a partir, é verdade, da experiência alemã da tradução ${ }^{26}$ - com uma longa tradição de imitação, ao atacar o próprio texto em torno do qual, como vimos, a batalha da tradução e da imitação havia se desenrolado no século XVI. Em um artigo que esclarece de maneira notável a essência dessa tradução, Michel Foucault escrevia:

\begin{abstract}
O repentino retorno de nossas palavras aos "sítios" virgilianos faz a língua francesa transpor, em um movimento de retorno, todas as configurações que eram as suas. Ao ler a tradução de Klossowski, atravessa-se disposições de frases, colocações de palavras que foram as de Montaigne, Ronsard, do Romance da Rosa, da Canção de Rolando. Reconhece-se aqui as repartições do Renascimento, ali as da Idade Média, algures as da baixa latinidade. Todas as distribuições se sobrepõem, deixam ver, pelo único jogo das palavras no espaço, o longo destino da língua ${ }^{27}$.
\end{abstract}

Isso significa que, para partir o destino de imitação destinado à tradução na França, Klossowski remontou àquele tempo de nossa língua em que, ainda não real, era língua-de-tradução; língua aberta à comoção das línguas estrangeiras. O fato em si que esta tradução tenha sido possível, tenha conseguido ultrapassar o nível

\footnotetext{
${ }_{26}$ É por esse motivo que as críticas hostis referiram-se a seu propósito como «tradução germânica».
}

${ }^{27}$ L'Express, 29 de agosto de 1964. 
das tentativas experimentais, atingir o estatuto de uma obra (mesmo criticada), indica que o modo simbólico instaurado no século XVI começou, em profundidade, a desintegrar-se. Os quase vinte anos que transcorreram desde então confirmam essa reviravolta: as traduções da revista Poésie, da Bíblia (Meschonnic), de Freud, Heidegger, as que foram empreendidas por Clastres em Le Grand Parler, etc. demonstram que, pela primeira vez desde o classicismo (com exceção de alguns casos isolados como Chateaubriand traduzindo Milton), todo o horizonte da tradução e da relação com o Estrangeiro começou a abalar-se em nossa cultura. Lentamente, muito, muito lentamente, o sistema fechado da imitação dá lugar ao sistema aberto da tradução. Todavia, a tarefa permanece urgente, tão forte é a pressão do sistema da imitação etnocêntrica, de escrever uma verdadeira história da tradução na França, pois apenas uma reflexão histórica pode permitir-nos aqui escapar das miragens da ingênua repetição do Mesmo.

\section{Antoine Berman}

\section{L'Étranger ${ }^{28}$}

L'Étranger qui habite sur ma terre

Peut être vrai ou bon

Mais il ne parle pas ma langue

Et je ne sens pas sa raison.

Je vois le visage, les yeux et la bouche

Mais non son âme au fond.

Les hommes de ma propre souche

Peuvent être bons ou laids

Mais ils me disent des mensonges familiers, Aux mensonges que je dis, ils sont habitués;

Et nous n'avons pas besoin d'interprètes

Quand nous devons vendre et acheter.

$\overline{{ }^{28}}$ Este poema de Kypling, assim como as citações de Saint-Victor e Gontcharov estão presentes, em francês, no artigo de Berman. [Nota do Tradutor]

Cad. Trad., Florianópolis, v. 37, n⿳ 3, p. 280-304, set-dez 2017 


\section{L'Étranger qui habite sur ma terre \\ Peut être vil ou bon, \\ Mais du mouvement de ses humeurs \\ Je ne sais pas les forces ni les raisons; \\ Ni quand les Dieux de son pays lointain \\ De son sang s'empareront.}

Rudyard KIPLING

L'homme qui trouve sa patrie douce n'est qu'un tendre débutant ; celui pour qui chaque sol est comme le sien propre est déjà fort ; mais celui-là seul est parfait pour qui le monde entier est comme une terre d'exil. Hugues de SAINT-VICTOR, Didascalion.

Já refletiu, fez Oblomov, sobre o que significa a palavra os outros? Quer que eu te explique? [...] Um outro é um ser miserável, grosseiro, inculto, que vive na sujeira, na pobreza, que habita um sótão. Ele dorme sobre um tapete, se nutre de arenque e de batatas, a miséria o impele de um canto para outro...

Ivan GONTCHAROV, Oblomov.

Recebido em: 06/02/2017 Aceito em: 01/05/2017

Publicado em setembro de 2017 